\title{
SOIL CONSERVATION MEASURES: ASSESSMENT OF ECONOMIC EFFICIENCY IN TERMS OF UKRAINE
}

\author{
Shevchenko Oleksandr \\ National University of Life and Environmental Sciences of Ukraine
}

\begin{abstract}
The solution of preserving and restoring the soil fertility problem of agricultural lands in the process of economic activity is one of the main tasks in achieving global food security. Implementation of a complex of soil protection measures, as a rule, ensures the preservation and even growth of soil fertility. Therefore, the purpose of the article is to determine the economic efficiency of introducing soil protection measures in the use of agricultural land. For this purpose, the following tasks were set and solved: the analysis of the current state and trends of the land resources use in agriculture; to investigate the tendencies of carrying out measures on preservation of soil fertility and prevention of its degradation; to substantiate scientific and methodical estimation principles of economic efficiency of introduction of soil protection measures in the conditions of Ukraine.

The following basic methods were used to solve the research objectives: monographic analysis - when developing scientific publications on environmentally friendly use of agricultural land; comparative and statistical analysis - in studying the dynamics of the structure of the land fund of Ukraine by main types of land and economic activity; system-structural analysis and grouping - in the study of the nature and content of ecological and economic consequences of soil degradation, as well as approaches to assessing the economic effectiveness of soil protection measures; economic analysis and calculation of relative indicators - to evaluate the economic efficiency of soil protection measures in the process of agricultural land use; abstract-logical method - for theoretical generalizations and conclusions formation, etc.

Established that soil degradation is now one of the most important industrial and environmental issues, which is the main reason for the inability to achieve high rates of environmental and economic efficiency of land use in the future. It was also substantiated scientific and methodical approach to determining the economic efficiency of soil conservation measures in the current market conditions, which is based on the additional income that is received as a result of increase crop yields on protected lands. It is established that effective protection of soils from degradation is possible with the systematic implementation of soil protection measures complex, developed taking into account the specific natural and economic conditions of each region or agricultural enterprise. The priority directions of realization measures on land protection are given.
\end{abstract}

Key words: land protection, soil degradation, soil conservation measures, economic efficiency, agricultural lands, additional income.

\section{Introduction}

During the years of Ukraine's independence, the structure of agriculture and its specialization have changed significantly. Based on market-based land relations, predominantly specialized, commoditybased agricultural production oriented for export is developing. Modern agribusiness dynamically adapts to the needs of the national and world agrarian markets and refuses from unprofitable crops and livestock industries. In order to grow high harvests, the land is used extensively for agricultural purposes, resulting in the destruction of soil cover and the reduction of environmental sustainability of agro-landscapes.

Extensive management causes huge losses to the productive potential of the land fund and greatly reduces the stability of land to degradation processes. Soil degradation has recently been one of the most important industrial and environmental problems, without which it will be impossible to ensure high ecological and economic efficiency of land use by future generations in the future.

The solution of the problem of preserving and restoring the soil fertility of agricultural lands in the process of economic activity is one of the main tasks in achieving global food security. Research by scientists suggests that the implementation of a complex of soil protection measures, as a rule, ensures the preservation and even growth of soil fertility. This makes it possible to preserve the productivity of the land, even in the conditions of intensification of agriculture, to increase yields and gross collections of agricultural crops, and hence the value of agricultural land not only as objects of production activity, but also as components of the biosphere, which have an important environmental significance.

Modern scientific and theoretical provisions concerning the rational use and protection of agricultural land are reflected in the works of such domestic scientists as D. Babmidra (2010), D. Dobryak (2009), 
O. Kanash (2013), A. Martyn (2014), L. Novakovskii (1992), I. Rozumnyi (2009), A. Sokhnich (1998), A. Tretyak (2015) and others. On the other hand, the issues of ecological and economic use of natural resources were highlighted in their publications by such scholars as economists I. Bystryakov (2014), S. Ibatullin (2013), O. Sakal (2017), M. Khvesik (2010) and others.

Various aspects of the effective impact of soil protection measures, in particular, on increasing the productivity of agricultural land and suspending various land degradation processes, are reflected in works by M. Belotserkovsky (1984), D. Vanin (1987), P. Kasmir (2007), I. Kovalchuk (2013), M.Kopistinsky (1983), V. Krivov (2002), B. Maslov (1989), V. Medvedev (1977), I. Primak (2001), O. Tarariko (2009), N. Shelyakin (1990), V. Yukhnovsky (2012) and others.

However, many scholars, while investigating the issues of land and soil protection, often rely on the Soviet command and control model for land use management, which was based on central planning and budget financing of practically all soil protection measures, as well as on the assessment of the efficiency of agricultural production, mainly taking into account the volume of products received. In the current conditions, when land use is mostly based on private land and is based on a private entrepreneurial initiative, Ukrainian legislation in the field of land protection often becomes ineffective and characterized by the lack of clear norms (duties) to ensure their protection. Under these circumstances, an important task of the economy of nature management is the assessment of the effectiveness of soil protection measures in the current market conditions on the principle of cost / benefit, when the main measure of the efficiency of agribusiness is profit, rather than gross crop "at any price". Thus, the actual scientific and practical task is the development of modern approaches to the assessment of the effectiveness of soil protection measures, which should be based on market information and be suitable for real introduction into the practice of modern agribusiness.

Object of study - the process of determining the economic efficiency of introducing soil protection measures in the use of agricultural land.

Subject of study - theoretical, methodological and practical principles and directions for improving the assessment of the economic efficiency of soil protection measures in the use of agricultural land.

\section{Methodology of research and materials}

The theoretical and methodological basis of the research is the general theoretical methods of scientific knowledge, in particular, the dialectical method, system analysis, the fundamental positions of modern economic theory, the economics of nature management and environmental protection, the concept of sustainable development, the work of leading domestic and foreign scientists on the problems of protecting agricultural land. Materials of research: in the study used data of the state land cadaster, normative legal acts. Data and statistical data of the State Statistics Service of Ukraine and the State Service of Ukraine for Geodesy, Cartography and Cadaster have been used.

\section{Discussions and results}

Conducting from the beginning of the 1990s in Ukraine land reform significantly the structure of agricultural land tenure and land use. Thus, almost 12,000 former socialist agricultural enterprises (collective farms and state farms) were originally transformed into collective agricultural enterprises with the transfer of land to collective ownership, and in the future land was divided into separate shares (units). As a result, about 6.77 million Ukrainian citizens became owners of separate land plots of agricultural purpose, the average size of which is about 4 hectares.

During the time of the land reform in Ukraine, the ownership of land has changed significantly. Thus, as of 2016, privately owned 31060.0 thousand hectares (74.8\%) of agricultural land, state -10405.0 (25.1), collective - $17.4(0.04)$ and communal - 25. 5 thousand hectares (0.06\%) (Fig. 1). However, in recent years, the dynamics of ownership structure has slowed down considerably. In this regard, it can be argued about the actual completion of the transformation of ownership of land, and in agricultural land ownership began to dominate private property.

At present, the shredding and privatization of land shares (shares) by former members of collective farms did not become the basis for the development of a private peasant or farmer. The reason for this situation is that most owners of land shares (shares) are residents of rural areas of the working age who cannot independently process the land they have been given to them. Therefore, it is not surprising that the current land relations in agriculture in Ukraine have become leased. Owners of land shares (shares) transferred more than $2 / 3$ of the total number of land plots to be leased to agricultural enterprises for commercial agricultural production (Dobryak, Kanash, Babmidra, 2009; Koretsky, 2010). 


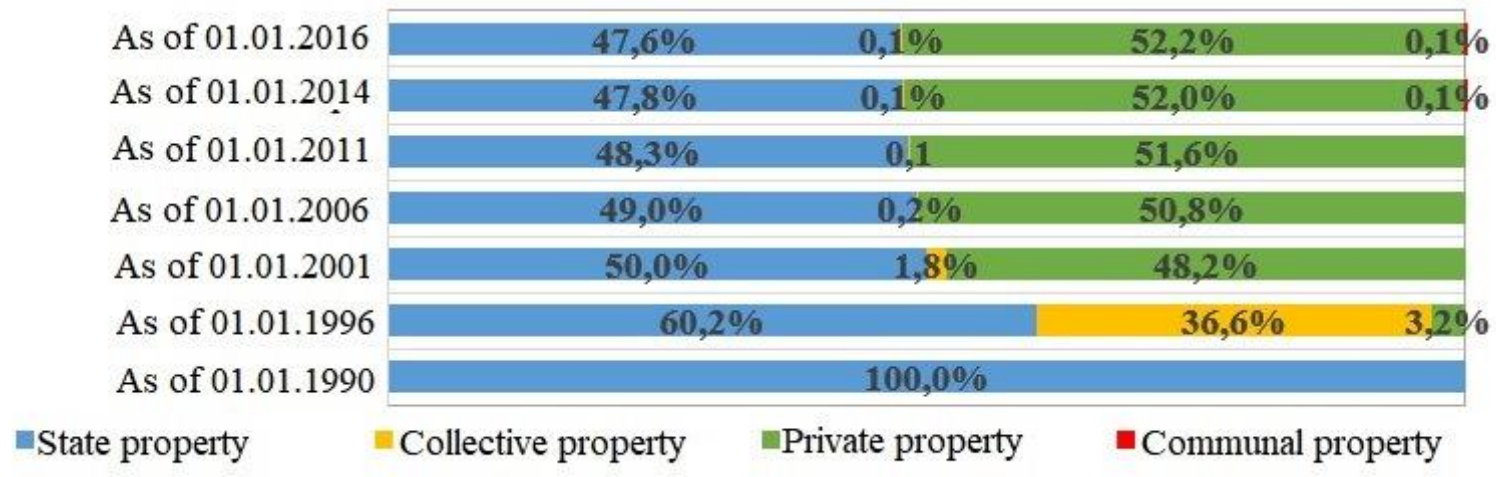

Fig. 1. Distribution of the land fund of Ukraine depending on the forms of ownership as of January 1, 1990-2016, \%

Rental of land as the main component of market land relations in agriculture should contribute to efficient management. Particular attention is paid to the improvement of lease land relations, the terms of the transfer of land to rent, which at the present stage of their development are very short. Indeed, the duration of the lease relations is inextricably linked with the tenant's intentions regarding the safe, rational and efficient use of land.

On average, in Ukraine, by the year 2017, there were about 16.5 million hectares of land leased, which was $59.7 \%$ of the total area of agricultural land owned by citizens. At the same time, the average amount of rent for land shares (shares) in Ukraine was 1093.4 UAH per 1 hectare. In Ukraine, over the past 17 years, the situation regarding the terms of land lease agreements has improved somewhat. So, if in 2001 the short-term lease for the term up to five years $(86.9 \%)$ prevailed, then in 2017 - the medium term is up to 10 years $(82.0 \%)$. At the same time, the share of recent contracts increased from 1.8 (2001) to $18.0 \%$ (2017).

In the course of land reform, landowners and land users are becoming more and more and the proportion of offenses in the field of land legislation is increasing proportionally. In order to improve the mechanism for exercising state control over the use and protection of land, preventing offenses in the field of land relations, as well as for the legal enforcement of measures to eliminate the violations of land legislation in Ukraine, a number of legal acts were developed. However, the current legislation of Ukraine in the field of land protection remains virtually inactive and is characterized by the lack of clear norms (responsibilities) regarding the provision of land protection. The only measure that must be met (by March 2015) by large landowners and land users is the drafting of environmental and economic rationale for crop rotation, which are often not followed up frequently (Tretyak and Tretyak, 2015).

Land users are not interested in the long-term preservation of productive properties of land that is not their property and with which they do not have long-term economic interests. In addition, owners of land plots were mostly elderly persons. They will never work on earth and they are mostly interested in maximizing income from leasing property. From the point of view of "big business", agriculture is often viewed as a short-term project aimed at maximizing revenue in current years without strategic plans for the future. Thus, Soviet approaches to land protection, which were based on central planning and budget financing of almost all soil protection measures and continuous land management, are no longer working in modern conditions. Instead, it is necessary to create conditions when the part of the rent received from agribusiness will be directed at financing of soil protection measures while ensuring state control over the rational use of land and observance of ground protection restrictions in land use.

The most important factor in reducing land productivity is their degradation. Even since Soviet times, it was known that the development of land was foreseen at the expense of the growth of agricultural land, especially arable land. This was almost the only measure to increase production. In this pursuit of additional centers of the product everything was ruined: steep slopes, protective zones along the reservoirs, pastures, roadside roads, etc. Extensive agricultural production in the post-Soviet area has led to catastrophic development of degradation processes in large agricultural areas.

Extensive management causes huge losses to the productive potential of the land fund of Ukraine and greatly reduces the stability of land against degradation processes (Fig. 2). Land degradation at present is one of the most important production problems, which does not allow to achieve high ecological 
and economic efficiency of land use. Among the developed lands, agricultural degradation is most often caused, which is caused by deep, sometimes irreversible transformations of vegetation and soil cover in the process of agricultural production (Dobryak, Babmidr, Slinchuk, 2010; Kovalchuk, 2013).

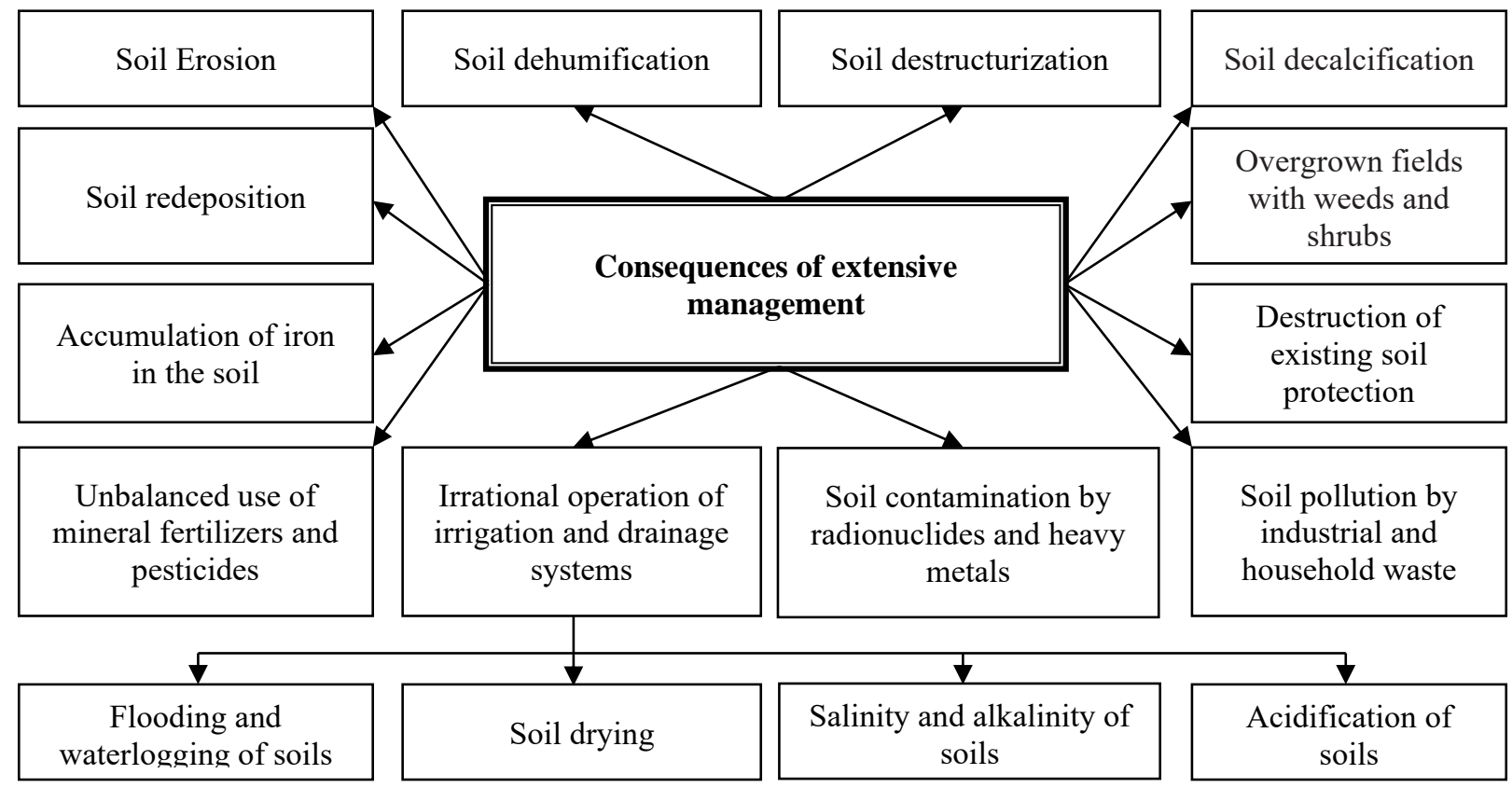

Fig. 2. Consequences of extensive land use

Human economic activity (anthropogenic factor) is the main cause of land degradation. As a result of degradation, the productivity of arable land decreases during their mechanical cultivation, which leads to spraying, flushing and blasting of soil cover and contamination by products of erosion of reservoirs. Therefore, it is necessary to clearly understand that degraded lands are very difficult, and sometimes it is impossible to revive at all.

Agricultural lands are located on 2/3 of Ukraine's territory. Their total area is 42776.9 thousand hectares, or $70.9 \%$ of the total land area, which indicates a high level of development (Fig. 3). Over the last decade in Ukraine, the area of agricultural land has decreased by 280.8 thousand hectares, while forests and other forest cover areas have increased by more than 197.8 thousand hectares; as well as the area of built-up land increased by 66.9 thousand hectares, and open wetlands - by 32.9 thousand hectares. However, the modern use of land cannot be considered ecologically safe. After all, the share of agricultural land accounts for $70.9 \%$ of the total area of the territory, which indicates the high level of its development. In addition, arable land occupies 32498.5 thousand hectares, which makes up $78.2 \%$ of the total area of agricultural land.

In Ukraine, rational use and protection of land resources are an important scientific, technical, organizational, agricultural and legal problem. The current land use structure does not meet the current economic and environmental requirements. In particular, the type and methods of using agricultural land have ceased to reflect the optimal correlation between natural conditions, the purpose of land use and the level of development of productive forces. This led to negative changes in the qualitative composition of land resources, especially agricultural land, most of which lose its fertility (very low and average humus content), has high acidity or salinity, is exposed to water or wind erosion (Krivov, 2002; Kanash, 2013). 


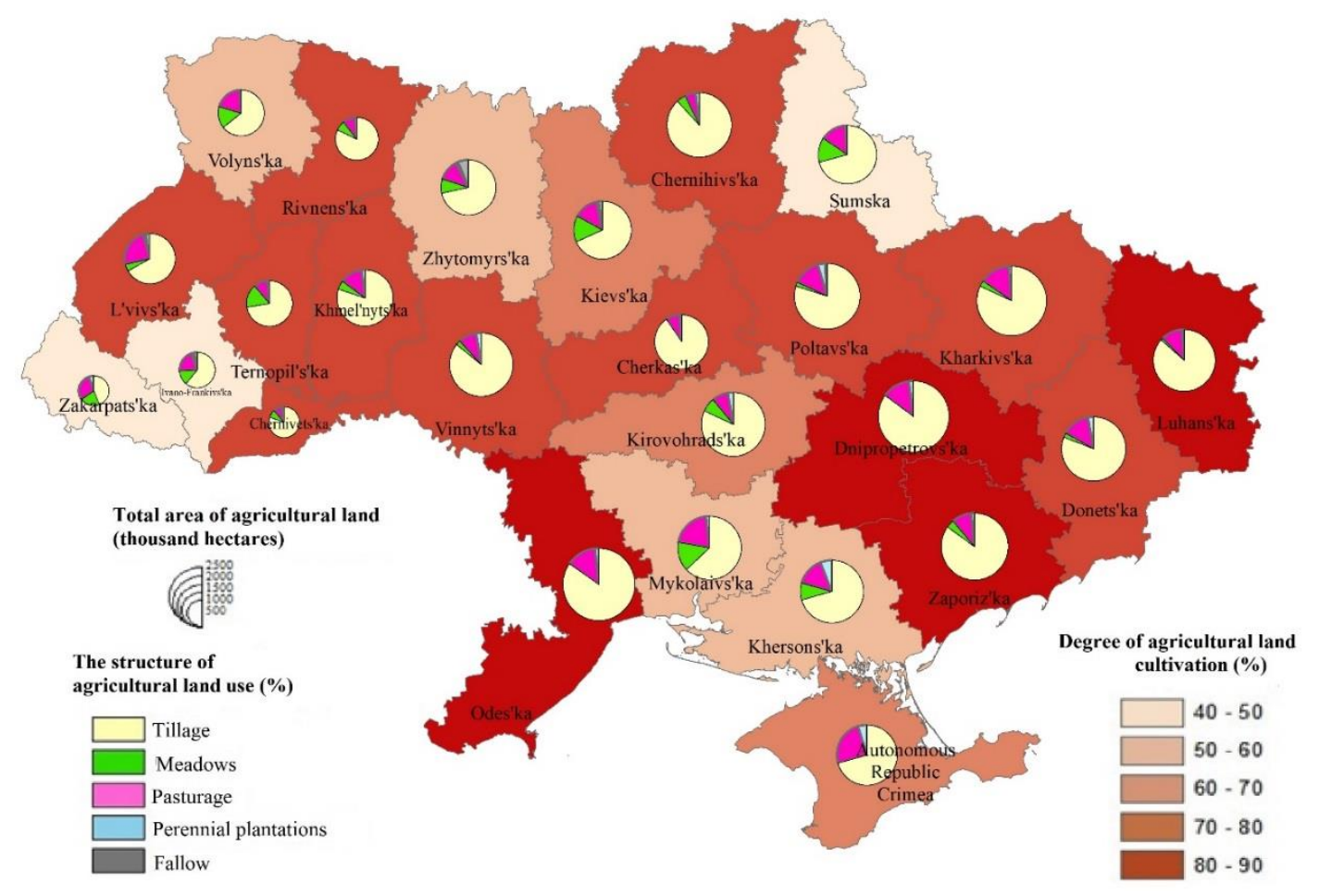

Fig. 3. The structure of agricultural land use in Ukraine

In order to avoid the imbalance and inefficiency of the land fund in modern agriculture, first of all, it is necessary to increase the productivity of the land with the help of scientifically grounded organization of the territory, introducing organizational, economic, agricultural, forest ameliorative and hydroamelioration measures in each agricultural enterprise; mainly to prevent unfavorable physical and geographical processes (erosion, excessive wetness, salinity, dryness, soil alkalinity, etc.).

Despite the urgent need to implement soil protection measures that will ensure not only preservation but also improvement of qualitative properties of agricultural land, Ukraine's current legislation in the field of land conservation remains low-level and is characterized by the lack of clear norms (responsibilities) for maintaining the quality of soils. Until March 2015, the only groundbreaking event for which failure was to be punished, it was considered mandatory for landowners and land users to develop draft ecological and economic rationale for crop rotation that often existed only on paper and subsequently ignored.

According to the data of the State Service of Ukraine on Geodesy, Cartography and Cadaster as of 01.01.2017, the total area of land that needs to be preserved is 1.1 million hectares, of which 564.9 are degraded, 482.0 are unproductive and 11.8 thousand hectares - technogenic polluted. During 2016, conservation of land with an area of 122 hectares was implemented, of which 56.3 were planted by felling and 65.7 hectares were planted. At the same time, the land, which are in the stage of conservation, cover almost 22.5 thousand hectares. The total area of disturbed lands in Ukraine is 143.4 thousand hectares, of which, during 2016, 146.2 hectares, including more than 81.6 hectares $(55 \%)$ of agricultural land, were reclaimed. The total area of land that is in the stage of reclamation exceeds 7 thousand hectares. In total, since 2002, only 46.8 thousand hectares of unproductive lands have been improved in Ukraine, in particular in 2016 - 110.6 hectares. At the same time, 315,600 hectares of land are in need of improvement, of which 2,600 hectares of land are under improvement, in particular 986.7 hectares (38\%) of arable crops (Коваленко, Щербаков, 1979).

The problem of land protection in Ukraine was particularly aggravated with the onset of the reform of land relations, which was aimed primarily at the privatization of land. If till 1990 the maintenance of soil fertility was based on state support, and agricultural producers practically carried out the whole complex of works on soil protection, then, since the first years of independence of our state, the situation has changed considerably, and issues of protection of agricultural land began to devote less and less attention. Thus, according to the data of the State Service of Ukraine on Geodesy, Cartography and Cadaster, since 2002 construction (reconstruction) of anti-erosion hydraulic 
engineering structures was carried out: shafts, ditches $-58.6 \mathrm{~km}(0.5$ hectares $)$; terraces $-21.7 \mathrm{~km}$; road rails - $41.9 \mathrm{~km}$; runoff structures - 150 units; terracing of slopes - 6 units. (2.8 ha); anti-erosive ponds - 46 units. $(585.1 \mathrm{ha})$; coastal protection $-120.6 \mathrm{~km}$ (0.7 hectares); the other - 658.4 hectares, 17 units, $51.7 \mathrm{~km}$. Due to the very costly logistics costs, in recent years the liming of soils was conducted on the average in the area of 1.9-5.6 thousand hectares from the estimated 40.0-50.0 thousand hectares, while the soil gypsum was practically non-existent (Martyn and Shevchenko, 2014; Shevchenko and Martyn, 2016).

It is impossible to solve the problem of land degradation by some soil protection technique; therefore, it is expedient to implement measures to protect them on the basis of a program-targeted approach. It has been established that the economic effectiveness of soil protection measures will be ensured by preventing losses caused by land degradation and corresponding decrease of their productivity, as well as by obtaining additional income for improving the spatial conditions of agriculture. Effective protection of soils from degradation is possible for the systematic implementation of a complex of soil protection measures taking into account specific natural and economic conditions. Ground-protection measures include a number of anti-degradation techniques, namely: organizational-economic, agro technical, cultural, forest-demanding and hydro-amelioration. Each of them differs as a way to protect and restore the fertile soil layer, as well as economic parameters - the amount of financing for their implementation, the net additional income from their implementation, the payback period of the investment and the amount of the prevented damage.

On the basis of the analysis of the economic efficiency of soil protection measures, it has been established that at present, organizational, economic and agronomic measures are the most suitable in comparison with other soil protection anti-degradation techniques. They are the most affordable, do not require high labor costs and funds, but they give a noticeable increase in yields already in the first years of their application. At the same time, the most time-consuming payback period is hydroamelioration and other measures that require significant investment in construction work.

Out of the total number of 49 soil protection measures identified, there are 12 measures with a payback of more than 8 years (costs are higher than the profit), the average efficiency is 5 (cost will be paid back in 4-8 years), highly effective, with a payback period of less than 4 years - 33 In addition, a soil protection measure such as conservation of land was investigated, which should be considered only through the ecological effect, in the form of the re-naturalization of the environment (restoration of the natural state) (Table 1) (Медведев, Майоров, 1977; Маслов, Минаев, Губер, 1989; Шелякин, Белолипский, Головченко, 1990).

The results of the study indicate that there is no doubt about the necessity of full-scale practical implementation of soil protection measures in farms. However, the tendency nowadays to implement a system of measures for protecting soils and preventing their degradation is evidence of the opposite. The only correct step in solving this problem is to develop at the legislative level the mechanism of economic stimulation of land owners and land users to implement soil protection measures. 
Table 1

Economic effectiveness of soil protection measures implemented in agriculture *

\begin{tabular}{|c|c|c|c|c|c|c|}
\hline & Measure & $\begin{array}{c}\text { Specific } \\
\text { costs, } \\
\text { UAH/ha }\end{array}$ & $\begin{array}{c}\text { Add. } \\
\text { income, } \\
\text { UAH }\end{array}$ & $\begin{array}{c}\text { Effect of } \\
\text { events, } \\
\text { UAH/ha }\end{array}$ & $\begin{array}{c}\text { Effective } \\
\text { ness of } \\
\text { active, \% }\end{array}$ & $\begin{array}{l}\text { Payback } \\
\text { costs, years }\end{array}$ \\
\hline 1. & $\begin{array}{l}\text { Contour-horizontal positioning of the boundaries of } \\
\text { the fields }\end{array}$ & 25.00 & 409.64 & 384.64 & 1538.56 & $<0.5$ \\
\hline 2. & Organization of crop rotation & 35.00 & 320.28 & 285.28 & 815.09 & $<0.5$ \\
\hline 3. & Strip placement of crops & 115.97 & 426.36 & 310.39 & 267.65 & $<0.5$ \\
\hline 4. & Soil processing $* *$ & 324.27 & 418.70 & 94.42 & 152.04 & 0.9 \\
\hline 5. & Mulching of soil & 1080.00 & 401.28 & -678.72 & -62.84 & 2.7 \\
\hline 6. & Soil slotting & 157.00 & 476.52 & 319.52 & 203.52 & $<0.5$ \\
\hline 7. & Melting the ground & 141.30 & 543.40 & 402.10 & 284.57 & $<0.5$ \\
\hline 8. & Transverse bending of the hay & 94.20 & 292.60 & 198.40 & 210.62 & $<0.5$ \\
\hline 9. & Intermittent furrowing of the hail & 100.48 & 292.60 & 192.12 & 191.20 & $<0.5$ \\
\hline 10. & Cross-fertilization method & 233.00 & 585.20 & 352.20 & 151.16 & $<0.5$ \\
\hline 11. & Coulomb (protective) crops & 115.97 & 376.20 & 260.23 & 224.39 & $<0.5$ \\
\hline 12. & Buffer strips of perennial grasses & 149.50 & 501.60 & 352.10 & 235.52 & $<0.5$ \\
\hline 13. & Clearing of areas from stones (up to $25 \mathrm{~m} 3$ ) & 3815.10 & 459.80 & -3355.30 & -87.95 & 8.3 \\
\hline 14. & Clearing of squares from shrubs and small-leafed trees & 4396.00 & 359.48 & -4036.52 & -91.82 & 12.2 \\
\hline 15. & Destruction of shrubs by milling & 4710.00 & 384.56 & -4325.44 & -91.84 & 12.2 \\
\hline 16. & Plowing shrubs with a shrub and marsh plow & 816.40 & 501.60 & -314.80 & -38.56 & 1.6 \\
\hline 17. & Roasting of stumps (100 pcs.) & 1884.00 & 418.00 & -1466.00 & -77.81 & 4.5 \\
\hline 18. & Destruction of bumps at a height of $15-50 \mathrm{~cm} * *$ & 2092.45 & 334.40 & -1758.05 & -80.92 & 6.2 \\
\hline 19. & Development (removal) of turf & 1238.42 & 551.76 & -68.66 & -55.45 & 2.2 \\
\hline 20. & Surface planning and alignment of shafts and heap & 376.80 & 501.60 & 124.80 & 33.12 & 0.8 \\
\hline 21. & Snow removal and snowmaking regulation & 84.47 & 367.84 & 283.37 & 335.47 & $<0.5$ \\
\hline 22. & Improvement of the areas of natural forage land** & 1223.60 & 892.25 & -331.25 & 32.99 & 1.2 \\
\hline 23. & Conservation of lands (pasture, afforestation)** & 3848.38 & - & - & - & - \\
\hline 24. & Land reclamation by depth of depth $0.20 \mathrm{~m}$ & 62597.10 & 1162.04 & -61435.06 & -98.14 & 53.9 \\
\hline 25. & Falling up and laying the ravines (up to 5-9 $\mathrm{m}$ )** & 392500.00 & 777.48 & -391722.52 & -99.76 & $>100$ \\
\hline 26. & Steering the steep slopes & 20410.00 & 710.60 & -19699.40 & -96.52 & 28.7 \\
\hline 27. & Liming or gypsum soil (in the norm of $1-8 \mathrm{t} / \mathrm{ha}$ ) $* *$ & 910.57 & 735.68 & -174.89 & 12.81 & 1.2 \\
\hline 28. & $\begin{array}{l}\begin{array}{l}\text { Introduction of organic fertilizers (at rates of } 10-40 \\
\text { t/ha)** }\end{array} \\
\end{array}$ & 6364.32 & 1070.08 & -5294.24 & -78.38 & 5.9 \\
\hline 29. & $\begin{array}{l}\text { Introduction of nitrogen fertilizers (in the norm } 200 \text { - } \\
800 \mathrm{~kg} / \mathrm{ha})^{* *}\end{array}$ & 1472.00 & 1479.72 & 7.72 & 26.68 & 1.0 \\
\hline 30. & $\begin{array}{l}\text { Application of phosphorus fertilizers (in the norm 200- } \\
800 \mathrm{~kg} / \mathrm{ha} \text { ) } * *\end{array}$ & 1222.00 & 593.56 & -628.44 & -39.17 & 2.1 \\
\hline 31. & $\begin{array}{l}\text { The introduction of potassium fertilizers (in the norm } \\
200-800 \mathrm{~kg} / \mathrm{ha})^{* *}\end{array}$ & 1912.00 & 501.60 & -1410.40 & -66.70 & 3.8 \\
\hline 32. & Application of green fertilizers (green manure crop) & 1063.97 & 978.12 & -85.85 & -8.07 & 1.1 \\
\hline 33. & Trimming of weeds & 198.82 & 468.16 & 269.34 & 135.47 & $<0.5$ \\
\hline 34. & $\begin{array}{l}\text { Application of herbicides (at the rate of application } \\
0.4-0.61 / \mathrm{ha} \text { ) }\end{array}$ & 273.20 & 618.64 & 345,44 & 126.44 & $<0.5$ \\
\hline 35. & Creation of irrigation system** & 12258.33 & 1580.04 & $-10678,29$ & -86.47 & 7.7 \\
\hline 36. & Creating a drainage system $* *$ & 26452.06 & 1237.28 & $-25214,78$ & -95.10 & 21.4 \\
\hline 37. & Creation of field protecting forest bands & 166.40 & 618.64 & 452.24 & 271.78 & $<0.5$ \\
\hline 38. & Creation of stock-control forest bands & 228.59 & 618.64 & 390.05 & 170.63 & $<0.5$ \\
\hline 39. & Creation of riverside and lush forest bands & 458.44 & 601.92 & 143.48 & 31.30 & 0.8 \\
\hline 40. & $\begin{array}{l}\text { Establishment of afforestation around reservoirs and } \\
\text { along the banks of rivers }\end{array}$ & 547.93 & 543.40 & -4.53 & -0.83 & 1.0 \\
\hline 41. & Creation of forest plantations on slopes of ravines, etc. & 628.00 & 476.52 & -151.48 & -24.12 & 1.3 \\
\hline 42. & Creation of forest plantations on sands & 384.65 & 418.00 & 33.35 & 8.67 & 0.9 \\
\hline 43. & Construction of water-retaining, ditches & 5648.86 & 451.44 & -5197.42 & -92.01 & 12.5 \\
\hline 44. & Construction of nautical shafts-terraces & 242.09 & 376.20 & 134.11 & 55.40 & 0.6 \\
\hline 45. & $\begin{array}{l}\text { Construction of bottom sediments from willow and } \\
\text { vines }\end{array}$ & 345.40 & 376.20 & 30.8 & 8.92 & 0.9 \\
\hline 46. & Construction of bottom sediments made of stone & 13816.00 & 376.20 & -13439.80 & -97.28 & 36.7 \\
\hline 47. & $\begin{array}{l}\text { Construction of bottom sediments from reinforced } \\
\text { concrete }\end{array}$ & 17270.00 & 376.20 & -16893.80 & -97.82 & 45.9 \\
\hline 48 & Construction of fluctuations, fast moving stone & 38936.00 & 434.72 & -38501.28 & -98.88 & 89.6 \\
\hline 49. & $\begin{array}{l}\text { Construction of fluctuations, fast-moving concrete } \\
\text { from reinforced concrete, concrete }\end{array}$ & 48670.00 & 434.72 & -48235.28 & -99.11 & $>100$ \\
\hline
\end{tabular}

Notes: * Calculated by the author; ** Average values 


\section{Conclusions and proposals}

The problem of preservation and restoration of the soil fertility of agricultural land in the process of economic activity is one of the most important tasks of the society. After all, the implementation of measures for soil protection, reproduction and enhancement of their fertility in the intensification of agriculture contributes to the increase of crop yields and gross crops, as well as increases the value of agricultural land not only as objects of production activity, but also as components of the biosphere, while having a large conservation value.

However, nowadays in Ukraine tendencies of soil protection measures to preserve soil fertility and to prevent their degradation demonstrate a significant reduction in their implementation. In this regard, it is necessary to develop at the legislative level a mechanism for economic incentives for land owners and land users to implement soil protection measures. Therefore, it is necessary for this:

- to encourage land owners and land users to implement soil protection measures through mechanisms of state support for agriculture, rational use of available limited budget resources;

- to motivate landowners and land users to implement soil protection measures based on fiscal instruments, in particular, to allow the use of preferential tax treatment (fixed tax, single tax, special VAT refund regime, etc.) only for those land users who take measures for protection of soils, and in cases of recultivation or the conservation of land is exempt from payment for land;

- to compensate at the expense of budget funds (including those received in order to compensate for losses of agricultural production), the part of expenses of landowners and land users on soil protection measures, especially on medium and low-efficiency ones, which are important ecological significance (construction of hydro-technical structures, filling and laying of ravines, etc.);

- to register ground protection restrictions in land use in the course of conducting the State Land Cadaster, controlling in the future their observance in the order of state, self-government and public control over the use and protection of land;

- to apply a mechanism of preferential lending with state support for those land users who implement soil protection measures;

- to wide promotion of best land-use practices in land use among agribusiness entities, especially those with long-term business strategies, since a significant number of soil conservation measures maintain their economic attractiveness for agribusiness even in market conditions;

- to encourage landowners and land users to comply with soil protection requirements, increasing the amount of fines for violation of norms of rational land use to the level of real social losses due to land degradation.

\section{References}

1. Dobryak D., Babmidr D., Slinchuk V. (2010) Формування екологобезпечного землекористування в умовах дії водної та вітрової ерозії (Formation of ecologically safe land use in conditions of water and wind erosion). Київ: Урожай, 2010, 152 c. (in Ukrainian).

2. Dobryak D., Kanash O., Babmidra D. (2009) Класифікація сільськогосподарських земель як наукова передумова їх екологобезпечного використання (Classification of agricultural land as a scientific prerequisite for their ecologically safe use). Київ: Урожай, 2009. 464 c. (in Ukrainian).

3. Kanash O. (2013) Грунти - провідна складова земельних ресурсів (Soils - the leading component of land resources). Землеустрій і кадастр. 2013, № 2. с. 68-76 (in Ukrainian).

4. Koretskiy A.V. (2010) Удосконалення правового регулювання охорони земель (Improving the legal regulation of land conservation). Економічні науки. Вісн. ХНАУ. 2010, № 6. с. 204-210 (in Ukrainian).

5. Kovalchuk I. (2013) Ерозійні процеси Західного Поділля: польові, стаціонарні, експериментальні та морфометричні дослідження (Erosion processes of Western Podillya: field, stationary, experimental and morphometric studies). Київ-Львів: Ліга-Прес, 2013. 296 с. (in Ukrainian).

6. Krivov V. (2002) Екологічна стабілізація агроландшафтів та створення екологічної мережі в Україні (Ecological stabilization of agro-landscapes and creation of an ecological network in Ukraine). Містобудування та територіальне планування. 2002, № 13. C. 117-120 (in Ukrainian).

7. Martyn A., Shevchenko O. (2014) Землеустрій сільських територій як передумова збереження агроландшафтів (Landscaping of rural territories as a prerequisite for the preservation of agro-landscapes). Збалансоване природокористування. 2014, № 2. С. 102-106 (in Ukrainian).

8. Shevchenko O., Martyn A. (2016) Економічна ефективність грунтоохоронних заходів при використанні земель сільськогосподарського призначення (Economical Efficiency of Soil Conservation Measures in Agricultural Land-Use). Київ: ЦП «Компринт», 2016. 332 с. (in Ukrainian). 
9. Tretyak A., Tretyak V. (2015) Поняття, сутність та зміст раціонального використання землі: теорія, методологія та практика (Concept, essence and content of rational land use: theory, methodology and practice). Землевпорядний вісник. 2015, № 8. с. 21-25 (in Ukrainian).

10. Коваленко А.П., Щербаков В.И. (1979) Эрозии заслон (Erosion of the barrier). Донецк: Донбас, 1979. 248 c. (in Russian).

11. Маслов Б.С., Минаев И.В., Губер К.В. (1989) Справочник по мелиорации (Reference book on land reclamation). Москва: Росагропромиздат, 1989. 384 с. (in Russian).

12. Медведев Н.В., Майоров Ю.И. (1977) Расчет экономической эффективности противоэрозионных сооружений (Calculation of the economic efficiency of anti erosion structures). Гидротехника и мелиорация. 1977, № 8. C. 90-93 (in Russian).

13. Шелякин Н.М., Белолипский В.А., Головченко И.Н. (1990) Контурно-мелиоративное земледелие на склонах (Conturno-reclamation agriculture on the slopes). Київ: Урожай, 1990. 168 с. (in Russian).

\section{Information about author:}

Oleksandr Shevchenko, PhD (Economics), Associate Professor in Department of Geodesy and Cartography, National University of Life and Environmental Sciences of Ukraine, 13 Vasilkovskaya Str., Kyiv, 03040,

Ukraine, shevchenko_ov90@ukr.net

ORCID ID: http://orcid.org/0000-0002-1485-5646 